$11-8-2010$

\title{
Diatoms as Indicators of Water-level Change in Freshwater Lakes
}

Julie A. Wolin

Cleveland State University, j.wolin@csuohio.edu

Jeffrey R. Stone

Follow this and additional works at: https://engagedscholarship.csuohio.edu/scibges_facpub

Part of the Aquaculture and Fisheries Commons, and the Biology Commons

How does access to this work benefit you? Let us know!

Publisher's Statement

(c) 2010 Cambridge University Press

\section{Recommended Citation}

Wolin, J.A. and J.R. Stone, 2010. Diatoms as Indicators of Water-Level Change in Freshwater Lakes. In: The Diatoms Applications to the Environmental and Earth Sciences, E.F. Stoermer and J.P. Smol (eds.), Cambridge University Press. pp.174-185.

This Contribution to Books is brought to you for free and open access by the Biological, Geological, and Environmental Sciences Department at EngagedScholarship@CSU. It has been accepted for inclusion in Biological, Geological, and Environmental Faculty Publications by an authorized administrator of EngagedScholarship@CSU.

For more information, please contact library.es@csuohio.edu. 


\title{
Diatoms as indicators of water-level change in freshwater lakes
}

\author{
JULIE A. WOLIN AND JEFFERY R. STONE
}

\subsection{Introduction}

Water-level changes result from a variety of geological, biological, and/or climatic processes. Many of these changes occur over long periods; others may be rapid or result from catastrophic events. In aquatic environments, diatoms are highly sensitive indicator organisms and their microfossils, deposited in lake sediments, can be used to infer environmental changes (Smol, 2008). Unambiguous diatom signals can be reconstructed from lakes isolated from marine or brackish waters (e.g. Fritz et al., this volume; Horton \& Sawai, this volume). However, in freshwater systems lake-level changes are often recorded as increases in planktonic (free-floating) diatoms although as discussed below, interpretation of this signal should be supported by additional evidence.

In the Laurentian Great Lakes region of North America (e.g. Finkelstein \& Davis, 2006; Wolfe et al., 200o; Wolin, 1996) and the North Sea and Baltic regions of Europe (e.g. Digerfeldt, 1998), freshwater lake levels are commonly affected by geological processes of isostatic rebound, subsidence, and outlet incision following glaciation, and lake isolation by coastalsediment transport (e.g. Karrow \& Calkin, 1985; Larsen \& Schaetzl, 200I; Lewis et al., 2008).

Biological processes, such as vegetation succession, can alter drainage patterns and groundwater flow, which in turn affect water levels. As vegetation develops following glaciation, surface runoff patterns change and this can moderate water levels on a seasonal or short-term basis. Natural deposition processes of internal (autochthonous) plant and animal remains, and mineral and organic inputs from the catchment (allochtonous) result in a shallower lake over time (Wetzel, 200I). These processes are accelerated by human activities such as forest clearance, farming, and nutrient inputs (e.g. Coops et al., 2003; Gaillard et al., I99I; Wolin \& Stoermer 2005), while dams and channelization by humans or other animals can result in rapid water-level changes.
Hydrology, however, is the most important factor controlling water level. Lake levels are a balance of moisture gains and losses. Inputs include: stream inflow, watershed runoff, groundwater inflow, and lake surface precipitation. Losses occur through stream outflow, lake surface evaporation, groundwater outflow, and, in some cases, deep seepage. Most of these hydrologic responses are associated with climatic or ecological change (e.g. Dearing, 1997).

The ability to determine past water-level changes in freshwater is particularly important for reconstructing past climate variation and developing predictive models for future climate change. Lake levels usually rise during wet periods and fall during dry phases. The magnitude of the corresponding sedimentary signal is dependent on lake type and its sensitivity to climate (some classic reviews include Richardson, 1969 and Street-Perrott \& Harrison, 1985). Shallow, closed-basin lakes usually record the strongest signals, while deep open-drainage and small surface-area lakes have the weakest. Unfortunately, from a paleo-reconstruction point-of-view, freshwater (opendrainage) lakes are predominant in many regions of the world and diatom-inferred reconstructions for these lakes are more problematic. Yu \& Harrison (1995) and Tarasov et al. (1994) compiled two of the first extensive lake-level climate-record data bases for European and northern Eurasian lakes, respectively. Many of the freshwater lake studies found in these data bases use qualitative changes in diatom communities to indicate high or low lake levels.

Several modern diatom and environmental factor data bases, useful in climate-response lake-level reconstruction, have been compiled and are available electronically through the European Diatom Database (EDDI) (Juggins, 200I) and the Diatom Paleolimnology Data Cooperative, the Academy of Natural Sciences, Philadelphia; the National Lakes Assessment diatom data base, US Environmental Protection Agency (USEPA), should be available by 2010. In many cases, human activities can alter or 
obscure climatic signals present in the record (e.g. Battarbee, 2000; Heinsalu et al., 2008). This is particularly true in areas where human activity has existed for centuries (Voigt et al., 2008). As the following examples will indicate, with proper consideration of limitations, it is possible to reconstruct waterlevel changes in freshwater systems. Given the number of freshwater lakes in regions where the only hydrologic signals will be found in such sedimentary archives, it is important to utilize these records to determine the effects of past climate change, geological events, or human manipulations.

\subsection{Types of diatom indicators}

Water-level fluctuations result in corresponding changes in available habitat, light, chemical conditions, stratification, and mixing regimes that indirectly affect freshwater diatom communities. When lake levels are low, usually more habitat is available for taxa living attached to substrates (benthos) or aquatic vegetation (epiphytes) because a greater area of the lake bottom is exposed to sunlight. Exceptions occur in steep-sided lakes or in shallow lakes where conditions may lead to greater turbidity or productivity-driven light limitation (e.g. Jeppesen et al., 2000; Vadeboncoeur et al., 2008), hence, it is necessary to use multiple lines of evidence to support any diatom-inferred water-level reconstructions and exclude factors that may result in comparable signals (Digerfeldt, I986; Smol \& Cumming, 2000). Such supporting data include: sediment stratigraphy, fine-grained particle analysis, stable-isotope analysis, chemical content, charcoal, chironomids, macrofossils, pollen, and ostracodes. Wind exposure can affect thermal structure, and, in shallow lakes, this can result in a total loss of stratification (e.g. Bennion et al., this volume). As nutrient and chemical concentrations increase, corresponding changes in $\mathrm{pH}$ occur (Fritz et al., this volume)

\subsubsection{Growth habit}

Numerous paleolimnological studies have used the plankticto-benthic (P:B) ratio to qualitatively infer water-level changes (e.g. Björck et al., 2000 in Denmark; Bergner \& Trauth, 2004; Ekblom \& Stabell, 2008 in Africa; Finkelstein et al., 2005 in Canada; Tarasov et al., 2000; Xue et al., 2003 in Asia; Tapia et al., 2003 in South America). Planktonic diatoms often dominate open-water environments, while benthic diatoms, epiphytes, and tychoplankton (accidental plankton) typically dominate littoral habitats. Shallow-water conditions expand benthic habitat and macrophyte growth producing a greater percentage of benthic and epiphytic forms preserved in lake sediments.
Conversely, during deeper lake phases, benthic substrates are often reduced, producing a greater percentage of plankton preserved in the sediment. The difficulty in using growth-habit ratio to reconstruct past environments is that the same signals may be caused by other factors.

The ratio of lake size to lake depth can affect benthic productivity, and, by extension, the size of the benthic diatom community. Vadeboncoeur et al. (2008) modeled benthic algal productivity across lake-size gradients using published lake to depth ratios and primary production estimates. They found that the contribution of benthic periphyton to whole-lake productivity was highest in high-latitude and oligotrophic shallow lakes (mean depth $<5 \mathrm{~m}$ ), and that such productivity declined as nutrients increased. In moderate-size oligotrophic lake systems (mean depth $=5-100 \mathrm{~m}$ ), benthic productivity contributed a substantially higher portion to whole-lake productivity, but decreased in importance with increasing nutrients. In agricultural regions, benthic productivity in eutrophic shallow lakes approaches zero as planktonic productivity increases and light limitation occurs.

In a shallow Estonian lake, Heinsalu et al. (2008) compared the sedimentary diatom record in a well-dated core to historic water-level fluctuations. They found close correlation of diatom growth-habit ratios with pre-eutrophication water levels, while yearly post-eutrophication water levels were only weakly or negatively correlated to percent planktonic diatoms (Figure 9.I). However, a strong correlation was found between post-eutrophication planktonic biomass and high spring water levels as short, mild winters facilitated earlier and prolonged planktonic diatom productivity.

Lake levels in early post-glacial lake sediments can be underestimated due to the abundance of benthic diatoms characteristic of nutrient-poor lakes and prolonged ice cover (Brugam et al., I998; Lotter et al., this volume). In alpine and high Arctic lakes, changes in growth habit ratio and increases in Fragilariacea often are indicative of ice-cover duration (Smol, I988; Lotter \& Bigler, 2000; Lotter et al.., this volume; Douglas and Smol, this volume). An investigation into abiotic influences on the distribution of Fragilaria and Staurosira species in oligotrophic and ultra-oligotrophic Austrian alpine lakes by Schmidt et al. (2004) found evidence of species size-variation with depth, in addition to depth correlation with benthic and planktonic taxa. Planktonic Fragilaria gracilis $\$$ strup had longer valves in deeper lakes, a potential competitive response to increase buoyancy. Further study on the correlation between species size-variation and depth may prove useful for water-level reconstruction. 


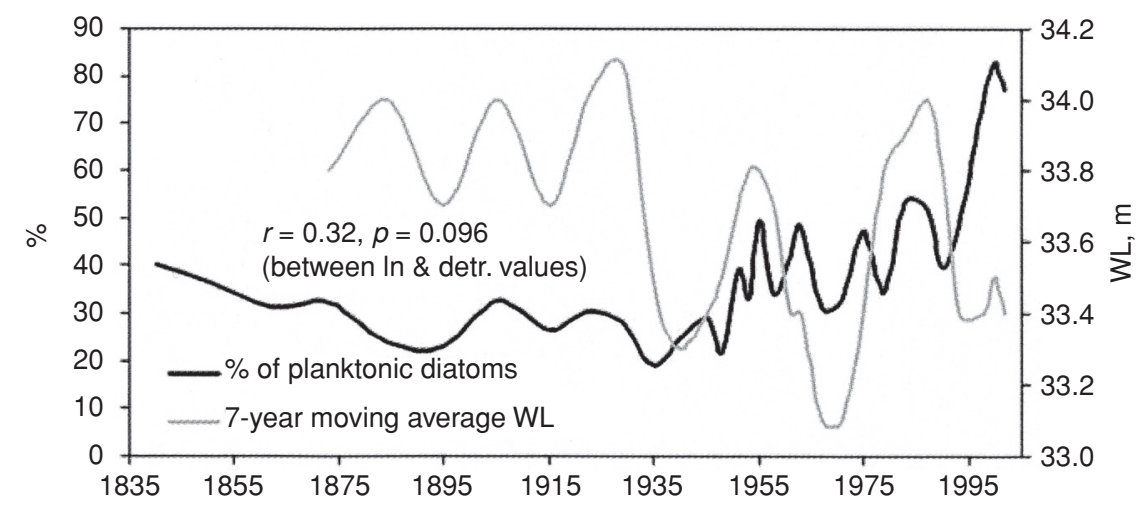

Figure 9.1 Relationship between measured water level (WL: sevenyear moving average) in Lake Vörtsjärv and the percentage of planktonic forms among diatoms in the sediment-core layers over the years 1873-2002. Reprinted with kind permission from Springer Science+Business Media: Hydrobiology, Water level changes in a large shallow lake as reflected by the plankton: periphyton-ratio of sedimentary diatoms. Vol. 599, 2008, page 28, Heinsalu, A., Luup, H., Alliksaar, T., Nõges, P. \& Nõges, T., Figure 5a. (C) Springer Science+Business Media B. V. 2007.

\subsubsection{Diversity}

Several investigators have noted an increase in diversity with increases in benthic diatom populations (e.g. Brugam et al., I998; Moos et al., 2005). Although highly dependent upon lake morphometry, as lake levels decline, planktonic species typically are replaced by a more diverse benthic community. Wolin (1996) reported increases in benthic/epiphytic diatoms in Lower Herring Lake, Michigan, as lake levels fell; however this increase did not persist during low-water periods, but was repeated as water levels rose again. Two studies on contemporary lake-level change give insight into mechanisms behind such diversity changes.

Turner et al. (2005) investigated the effect of lake drawdown on algal communities, and reported macrophyte diversity and cover decline with the loss of emergentvegetation and increased percentage of barren substrate as littoral area declined. An initial decrease in diatom diversity occurred following drawdown. Little change was observed in the plankton, but benthic algae declined due to disruption of habitat and loss of colonizable area. Although epiphytes were not considered separately, they could also provide an additional lake-level signal.

In Laguna de La Caldera, an oligotrophic mountain lake in the Spanish Sierra Nevada, Sánchez-Castillo et al. (2008) documented modern lake-level, nutrient, and diatom-community changes following a severe ro-year drought (1985-1995). In I996, a dramatic rise in lake level (from I.5 m to I5 m) resulted in increased bare substrate and a pulse of nutrients as

mineralization of organic matter occurred. This resulted in a drop in diatom diversity due to an initial dominance ( $93.3 \%$ by a pioneering benthic species. In the following two years, benthic diversity increased as communities developed and algal nutrient utilization increased.

\subsubsection{Physical and chemical environment}

Other diatom signals can be present as a result of environmental conditions caused by changes in water levels. These signals often reflect physical changes related to stability of the metalimnion, susceptibility to turbulence, nutrient or thermal conditions, or changes in pH (e.g. Bradbury et al., 2002). In deep-water cores from large lakes, where littoral influence is minimal, water-level fluctuations can be signalled by changes in the abundance of dominant planktonic taxa as they respond to such physical or chemical variables (e.g. Rioual et al., 2007). Most studies use these signals in conjunction with some form of littoral/planktonic shifts in reconstructing lake-level change.

\subsubsection{Turbulence}

Diatoms associated with turbulence regimes have proved useful in lake-level reconstructions, particularly in freshwater African lakes (e.g. Stager et al., I997; Verschuren et al., 2000; Bergner \& Trauth, 2004; Nguetsop et al., 2004; Stager et al., 2005). Aulacoseira species are heavily silicified diatoms with high sinking rates. Their ecology requires turbulence to remain in the photic zone (e.g. Bradbury et al., 2002) and they are often found in shallow eutrophic lakes in Europe (Rioual et al., 2007). Increased turbulence and corresponding nutrient increases during lowwater stages in a lake can favor this genus over other planktonic species.

The 15,000 year record of varved lake sediments from Elk Lake, Minnesota, is dominated by planktonic diatoms (Bradbury et al., 2002). Within this community, increases in the percentage of Aulacoseira indicate low-water conditions during a dry prairie period between 8500 and 4000 years ago. A 
combination of low-water conditions and high wind exposure provide the turbulent, high-nutrient conditions favourable to this taxon.

While turbulence is beneficial to heavy diatoms with high nutrient requirements, certain diatom species benefit from stable stratification during high-water periods in clear lakes (e.g. Cyclotella michiganiana Skvortzow, Fragilaria crotonensis Kitton). Diatoms living in the deep chlorophyll maximum (DCM) are adapted to low light and capture nutrients diffusing from the hypolimnion (Bradbury et al., 2002; Fahnenstiel \& Scavia, I987). Wolin (I996) used increases in taxa associated with the DCM to infer high water levels in Lower Herring Lake, Michigan.

\subsubsection{Nutrient environment}

Nutrient signals in diatom assemblages are commonly used to indicate human impacts within a lake basin (see Hall \& Smol, this volume). However, nutrient concentration also increases during low-water levels (Moos et al., 2009). If one can separate anthropogenic signals, these same indicators can be useful for climatic signals. In a small eutrophic lake in Northern Ireland, diatom-inferred total phosphorus increases resulted from climatic rather than anthropogenic forcings (Rippey et al., 1997). A dry period in the r97os resulted in reduced flushing and increased nutrients due to sediment phosphorus release. In a Michigan lake, Wolin \& Stoermer (2005) found a nutrientresponse-related lake-level signal in Cyclotella stelligera (Cleve et Grunow) Van Heurck during a record low-water phase in the I930s. While in Lake 239, Experimental Lakes Area increased percent abundances in the dominant planktonic C. stelligera was associated with higher lake levels (Laird \& Cumming 2008; 2009), this may be associated with the DCM and more stable stratification. Aulacoseira subarctica (O. Müll.) Haworth and F. crotonensis were found indicative of increased nutrient conditions in Lake 239 during large-magnitude lake-level drawdown in the mid Holocene (Moos et al., 2009). Verschuren et al. (2000) also found Aulacoseira responses to lake-level induced changes in nutrient and light levels in Lake Naivasha, Kenya. During deeplake/lower-nutrient conditions Aulacoseira ambigua (Grunow) Simonsen was dominant while Aulacoseira granulata (Ehrenb.) Simonsen dominated during shallow-lake/higher-nutrient and lower-light stages.

In shallow lakes, response to water-level disturbance is often non-linear (Coops et al., 2003) and can result in clear water and turbid lake phases, independent of nutrient enrichment and top-down effects. An overall decline in diatom productivity can occur during low-water phases, particularly in shallow lakes due to light limitation in benthic communities and nutrient limitation in plankton. Nõges et al. (2003) found that light limitation in the plankton community affected the abundance of diatom phytoplankton during high water levels, but that light and nutrient limitations during low water resulted in a community shift from diatoms to cyanobacteria.

9.2.6 pH

Climate changes, or more precisely wetter/drier shifts, are usually inferred indirectly in paleolimnological studies from evidence for water-level changes. Complex hydrologic interactions can result in $\mathrm{pH}$ shifts depending on the prevailing source. In Batchawana Lake, Ontario, early work by Delorme et al. (I986) connected moisture changes (i.e. lake level) determined by tree pollen data with prehistoric diatom-inferred $\mathrm{pH}$ changes (see Battarbee et al., this volume). Increases in humification and lower diatom-inferred $\mathrm{pH}$ prior to anthropogenicinduced causes were attributed to decreases in moisture, while high water levels resulted in increased circumneutral and alkaliphilous taxa (higher $\mathrm{pH}$ ). Krabbenhoft \& Webster (I995) provide mechanistic explanations for climate influence on $\mathrm{pH}$. They found that during drought conditions, reduced groundwater inflow containing high base-cation concentrations $\left(\mathrm{Ca}^{2+}, \mathrm{Mg}^{2+}\right)$ likely resulted in the acidification of Nevins Lake, Michigan. Increased percentages of acidophilic taxa can also indicate marginal wetland expansion during low-lake phases (e.g. Bunting et al., I997; Shkarpa, 2006).

In African lakes, diatom-inferred $\mathrm{pH}$ signals usually result in the opposite effect. Cation concentrations increase with drier climate, raising pH (e.g. Bergner \& Trauth, 2004; Fritz et al.., this volume). In the rainforest region of Cameroon, West Africa, Nguestop et al. (2004) found a more complex interaction in Lake Ossa where the $\mathrm{pH}$ of prevailing hydrological sources determined the dominant diatom community. During the rainy season, hydrology is dominated by low-pH precipitation ( $\sim 5$ to 6.8 ) and acidiphilic (low-pH) diatom taxa prevail. During the dry season, alkalinity and $\mathrm{pH}$ increase in the deepest regions of the lake with increased evaporation, but low-pH groundwater and wetland discharge maintain low-pH conditions $(<7)$ in littoral regions. Quantitative lakelevel reconstructions were based on growth-habit ratios and diatom-inferred $\mathrm{pH}$.

\subsection{Quantitative reconstructions}

Diatom/depth distribution studies, such as Round's (I96I) pioneering work in the English Lake District, remain uncommon. 
$\%$

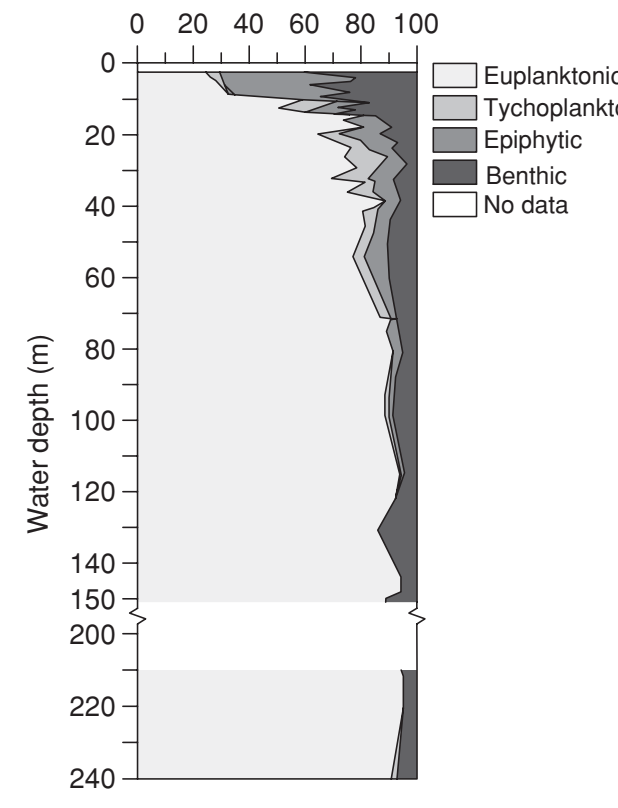

(a)

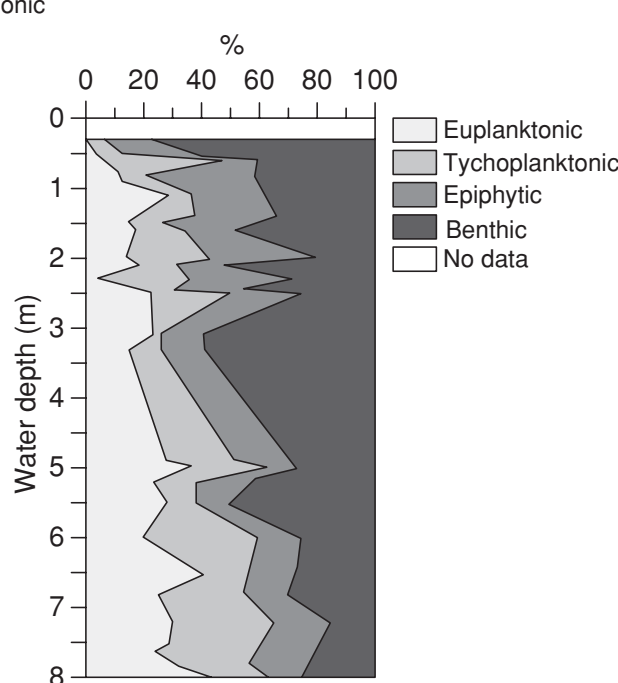

(b)

Figure 9.2 Relative abundance (\%) of diatom life forms from surficial sediment samples collected along depth gradients in (a) Lake Ontario, and (b) East Lake (Yang \& Duthie 1995).

The development of quantitative models for freshwater diatom inferred lake-level change has increased since the publication of Wolin \& Duthie (I999). New modeling techniques provide greater insight for interpreting changes in $\mathrm{P}: \mathrm{B}$ diatom sig nals (Stone \& Fritz, 2004) and researchers have increasingly focused on quantitative methods to successfully reconstruct lake-level changes (e.g. Laird \& Cumming, 2008, Moser et al., 2000; Nguestop et al., 2004; Rioual et al., 2007)

\subsubsection{Regression}

Early development of quantitative diatom-inferred depth models relied on regression to determine correlations between diatoms and depth. In most cases, taxa were subjectively assigned growth-habit categories based on the literature. In the North American Great Lakes, researchers (e.g. Stevenson \& Stoermer, I98I; Kingston et al., I983) quantified benthic diatom distributions along depth transects in Lake Michigan. Yang \& Duthie (1995) explored the distribution of euplanktonic, tychoplanktonic, epiphytic, and benthic life forms in transects along a $240 \mathrm{~m}$ depth gradient in western Lake Ontario, and an $8 \mathrm{~m}$ depth gradient in East Lake, an isolated embayment (Figure 9.2). Multiple regression was used to explore the relationship between measured water depth of surface samples and sample life-form composition. Strong relationships were found in both

lakes, though the stronger relationship in Lake Ontario was probably due to its greater depth, distance from the shoreline of the deeper samples, and a larger number of samples. The main problem with this approach was the subjectivity involved in the assignment of diatom taxa to life-form categories. Category assignments for each taxon were based on literature references and not all references agreed on life-form designations. Barker et al. (I994) developed an early quantitative model in Lake Sidi Ali, Morrocco, from depth-transect surface samples using preassigned habitat types: planktonic, tycoplanktonic, and littoral. They found a logarithmic relationship between depth (D) and the planktonic/littoral ratio $(\mathrm{P} / \mathrm{L})$; however, the literature-based growth-habit classification proved problematic in certain taxa (i.e. Fragilaria).

\subsubsection{Ordination}

Several researchers have continued the initial work of Lotter (I988) and Barker et al. (1994) using ordination methods (see Birks, this volume) to analyze contemporary diatom communities along surface-sediment depth transects, and identify depthspecific assemblages (e.g. Rautio et al., 2000). These assemblages have then been correlated to subfossil assemblages in cores and used to infer water depth (Lotter, I988). In Lake Ossa, Cameroon, Nguestop et al. (2004) reconstructed high and low lake levels using correspondence analysis (CA) of 74 modern diatom samples from local lakes to determine depth-defined assemblages. 


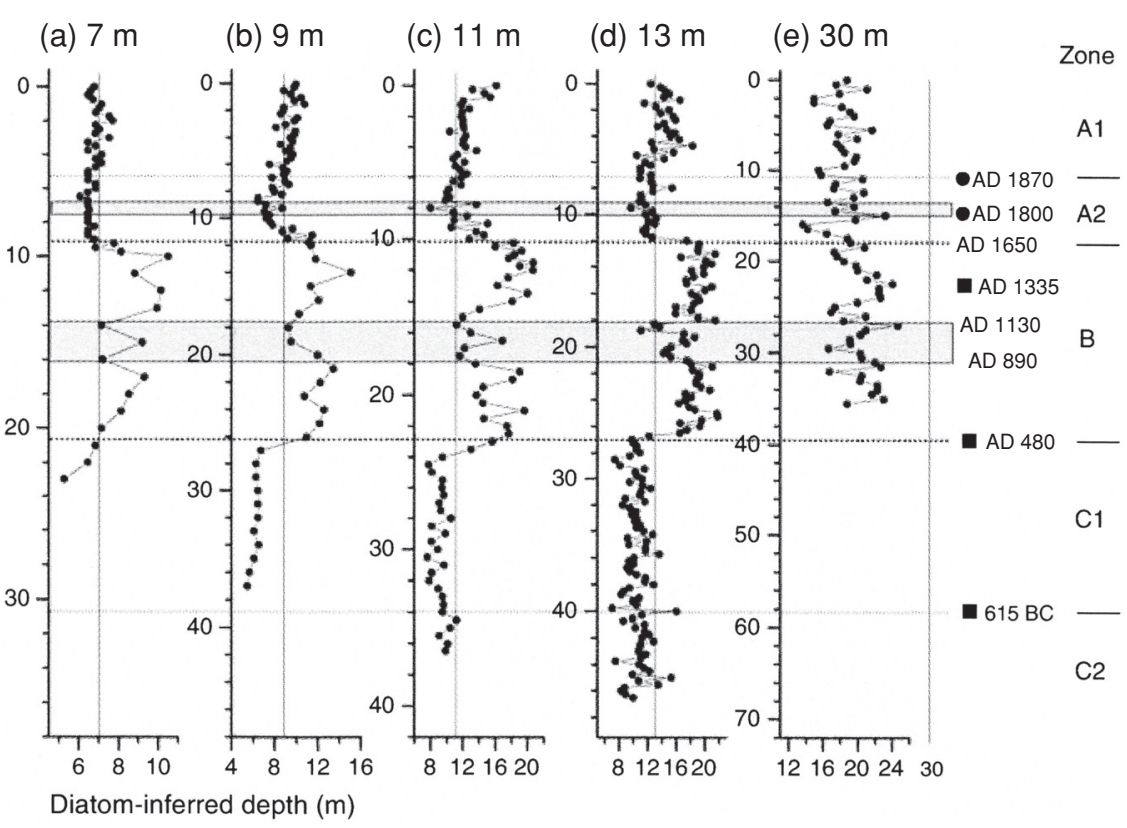

Figure 9.3 Diatom-inferred depth for each of the five gravity cores taken from depths ranging between 7 and $30 \mathrm{~m}$. Vertical lines indicate present-day depth at the respective coring sites. Gray bars indicate drought intervals. Solid circles indicate ${ }^{210} \mathrm{~Pb}$ chronology, solid squares indicate ${ }^{14} \mathrm{C}$ dating. Zones are based on a constrained cluster analysis of diatom assemblage data. (Reprinted from Journal of Paleolimnology, Vol. 42, 2009, Laird, K. R. \& Cumming, B. F., Diatom-inferred lake level from near-shore cores in a drainage lake from the Experimental Lakes Area, northwestern Ontario, Canada., Fig. 5, page 72, (c) 2008 with permission from Elsevier.)

9.3.3 Weighted-averaging analysis

The optimum abundance of a diatom along a depth or other environmental gradient such as temperature, $\mathrm{pH}$, or nutrient status can be determined by weighted-averaging (WA) analysis (Birks, this volume). Yang \& Duthie (1995) were the first to use WA analysis to determine optimum water depths for freshwater diatom species and develop training sets for lake-level reconstruction. Duthie et al. (1996) then applied this training set to reconstruct lake-level fluctuations in Hamilton Harbor, Lake Ontario. Yang \& Duthie (I995) cautioned, however, that WA can underestimate high levels and overestimate low levels. This trend, reported by other researchers (e.g. Brugam et al., I998), is attributed to functional interactions among different environmental variables not accounted for by simple inferences (Birks, this volume).

Two primary approaches have been used in developing training sets for freshwater lake-level reconstruction. One is to construct training sets from multiple depths across a small number of regionally close lakes (e.g. Brugam et al., I998) or from larger sets covering a greater lake size and geographic expanse (e.g.

Moser et al., 2000). The other is to construct lake-specific training sets (e.g. Barker et al., I994; Moos et al., 2005; Laird \& Cumming, 2008, 2009).

\subsubsection{Photic zone and diatom habitat availability}

Multiple authors sampling surface sediments along depth transects from the near shore to deep environs have observed a rapid transition zone where benthic diatoms dominate, and above which planktonic diatom deposition increases (see Figure 9.3) (e.g. Brugam et al., I998; Rautio et al., 2000; Moos et al., 2005; Punning \& Puusepp, 2007; Laird \& Cumming, 2008, 2009). Moos et al. (2005) found this corresponded to the region of $\mathrm{I} \%$ incident-light penetration and proposed this near-shore location should be the most sensitive for constructing lake-level inferences. Subsequent studies indicate that nearshore cores can provide such sensitive records (Laird \& Cumming, 2008; Laird \& Cumming, 2009). Several authors have emphasized the necessity of understanding light regime and habitat availability when using benthic and planktonic ratios as proxies for lake-level change. Early work by Earle et al. (I988), investigating patterns in sedimentary diatoms of three morphometrically different Canadian lakes, concluded that spatial heterogeneity in sample composition was a function of both water depth and basin morphometry (Figure 9.3).

The shape of a lake basin can have a profound influence on the habitat area available for diatom growth. Stone \& Fritz (2004) explored this relationship by developing a threedimensional modeling technique that calculated incremental changes in physical parameters of a lake (e.g. volume, planar 
(a)

\section{Bathymetric map of Foy Lake}

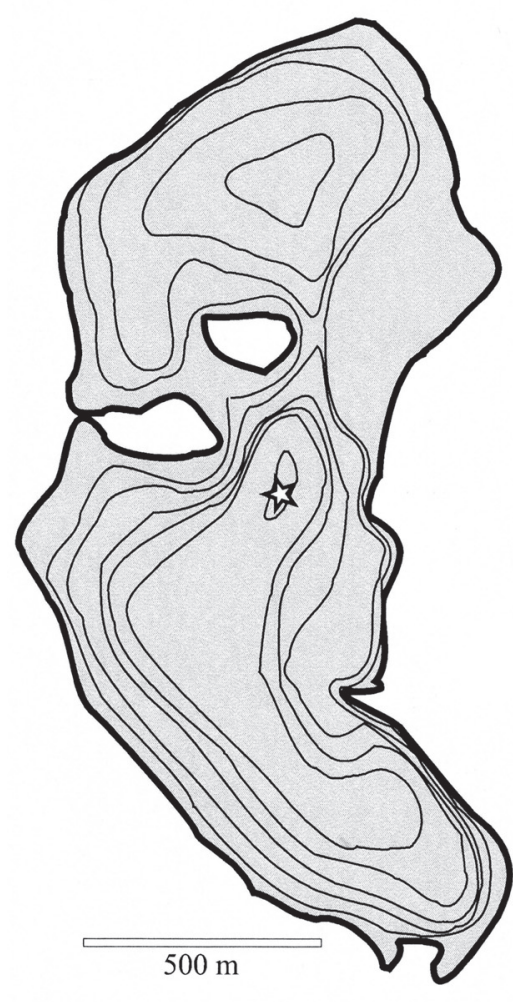

(b)

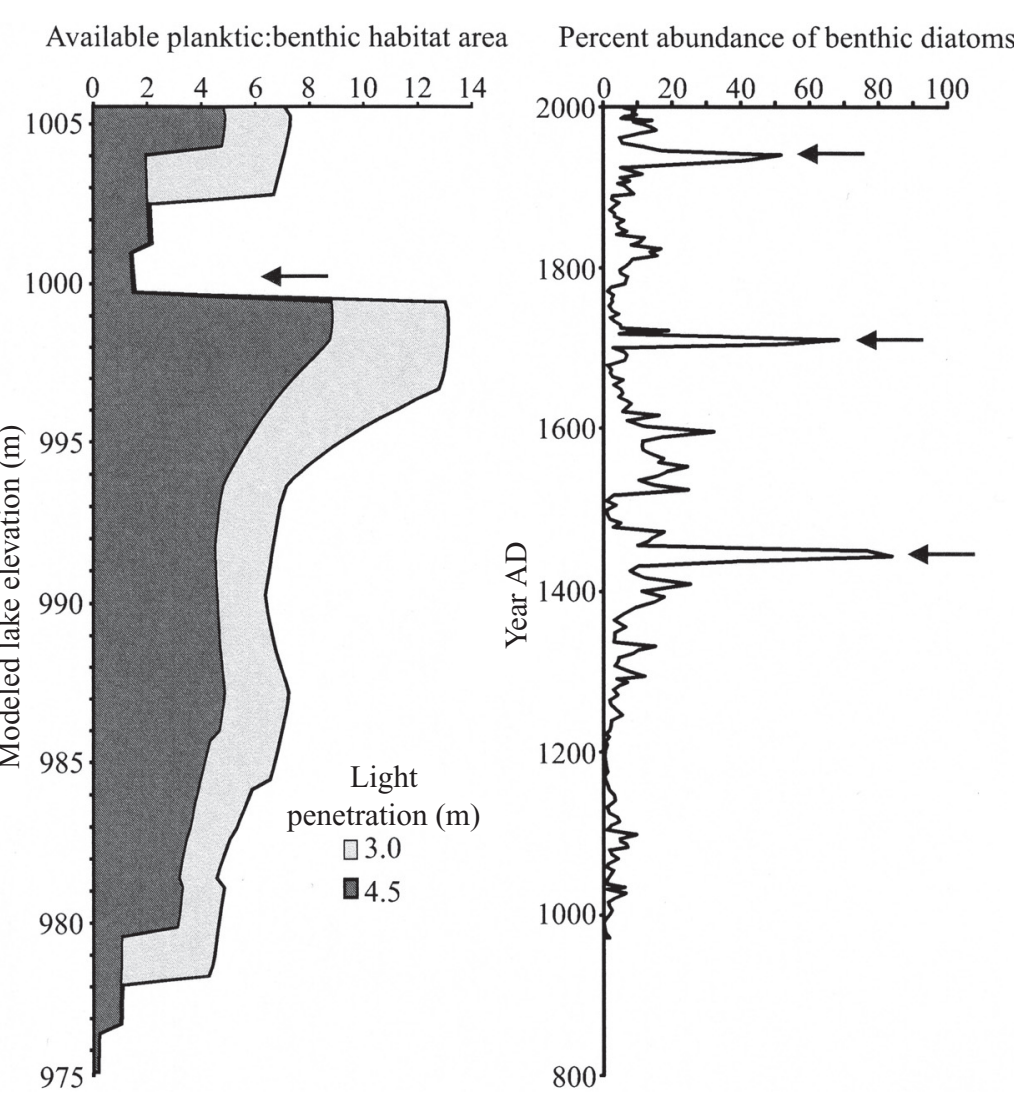

Figure 9.4 Modeling of available diatom habitat areas; modified from Stone \& Fritz (2004). (a) A bathymetric map of Foy Lake, Montana (contour interval $=20 \mathrm{feet} / 6.1 \mathrm{~m}$ ); the star indicates where core was taken. (b) Modeled changes in ratio of available diatom habitat area with depth at Foy Lake; the arrow indicates a benthic "notch", marking a rapid transition between available planktonic and benthic diatom habitat areas. (c) Percent abundance of benthic diatoms from sediment archives of Foy Lake; the arrows indicate spikes in the percentage of benthic diatoms related to specific lake elevations based on modeled changes in available diatom habitat areas.

surface area, lake bottom surface area) based on bathymetric and topographic maps of the basin and surrounding catchment (Figure 9.4a). Once these parameters were established for a given depth interval, the diatom habitat area available for planktonic and benthic diatom growth were calculated by making a few assumptions. The total planar surface area (water-air interface) greater than a depth of $\mathrm{I} .5 \mathrm{~m}$ was used to estimate the available planktonic habitat area. Because benthic diatom habitat requires sunlight and a substrate, the total area available for benthic diatom production was estimated by calculating the surface area of the basin (sediment-water interface) exposed to sunlight, under different values of light penetration. Then, for all discrete potential lake elevations, available planktonic to benthic diatom habitat area ratios were estimated (Figure 9.4b)

Modeled diatom habitat area ratios are probably not directly comparable to ratios of planktonic and benthic diatoms from sedimentary archives; however, they can provide context for changes observed in P:B in the sedimentary record. In lake systems with complex bathymetry, as in Foy Lake (Stone \& Fritz, 2004), P:B from sedimentary archives probably was a better indicator of mean lake depth than maximum lake depth. At some lake-surface elevations, a small change in lake level has the potential to produce a dramatic shift in relative ratio of available planktonic and benthic diatom habitat area. Rapid transitions appear as spikes or notches in the curve of modeled habitat availability with depth (Figure 9.4b) and represent a sharp break in basin slope, or a decoupling of mean depth from maximum depth. These transitions have the potential to produce "counter-intuitive" responses in diatom P:B in fossil sediments. By creating a sudden increase or decrease in the available habitat area for benthic diatom growth, rising lake levels could potentially increase the available benthic habitat area and lower the P:B. Conversely, a small drop in lake level has the potential to substantially decrease the available benthic habitat area, producing an increase in P:B, potentially 
confounding the standard interpretation of P:B in lake-level reconstructions.

Interestingly, in systems where rapid transitions occur, they can also provide a useful indicator of past lake level. Because spikes or notches in the modeled habitat area profile are tied to specific depths, when lake-level changes pass through these depths, a substantial change in P:B is likely to be observed in the sediment archives (Figure 9.4c). Well-constrained reconstruction of paleoclimate from fossil diatom assemblages in any lake system should incorporate an explicit consideration of lake-basin shape and how available planktonic and benthic habitat areas change with lake level; this is particularly true for lakes with complex bathymetry.

\subsection{Applications of diatom-inferred depth changes in lakes}

Ideally, the most sensitive signals of shoreline and water-level change will be found in marginal lake sediments that provide a sharp transition between planktonic and benthic assemblages (e.g. Battarbee, 2000; Digerfeldt, 1998). A multicore approach sampled along a depth gradient (e.g. Digerfeldt, I998) should provide a stronger $\mathrm{P}: \mathrm{B}$ response signal than that found in a single deepwater core. Models constructed from multiple lakes are not always as sensitive due to interactions between diatoms, habitat, and light availability and lake-specific training sets can produce a stronger, more applicable predictive model in many cases, from which robust diatom-inferred reconstructions can be made (Laird \& Cumming 2008, 2009). Unfortunately, appropriate marginal lake sediments are not always present in lakes, nor is it always feasible to take multiple transects when constructing multilake training sets. Significant diatom-depth relationships with high predictive ability have been developed from multilake training sets based on single deepwater cores (Brugam et al., I998; Moser et al., 2000; Rioual et al., 2007), but again, these must be interpreted in relationship to the additional factors that influence $\mathrm{P}: \mathrm{B}$ ratios.

9.4.1 Lake-specific quantitative modeling

Laird \& Cumming (2008) used multiple lines of evidence (fossil diatoms, scaled chrysophyte:diatom valve ratio and percent organic matter) to reconstruct past lake levels in Lake 239, Experimental Lakes Area (ELA), Ontario, Canada. Lake 239 was selected due to its predicted sensitivity to lake-level change based on size, depth, and catchment to lake area ratios (Dearing, 1997). Diatom species data from surface-sample depth transects (Moos et al., 2005) and additional samples were used to develop a quantitative depth model. This model was based on the modern analogue technique (MAT) (Birks, this volume; Juggins, 2007) because the relationship between diatoms and depth was not linear. Although the model was developed from samples at depths $\sim 2$ to $32 \mathrm{~m}$, it performed best when estimating depths less than $\sim$ IO- $12 \mathrm{~m}$, due to the predominance of $C$. stelligera in the deeper samples. Diatom-inferred depths identified two periods of climate-driven low lake-level declines of $\mathrm{I}-3 \mathrm{~m}$ during the late Holocene and $\geq 8 \mathrm{~m}$ during the arid mid Holocene. An extended period of high lake levels in the late Holocene was not adequately quantified with single-core analysis, however Laird \& Cumming (2009) were later able to quantify the high lake-level stands using multiple-core analysis

\subsubsection{Multi-lake quantitative modeling}

Rioual et al. (2007) provide an excellent example of freshwater diatom-inferred depth in their high-resolution quantitative climate reconstruction from fossil Eemian lake deposits in the French Massif Central (Figure 9.5). Using the extensive EDDI (Juggins, 200I), they established transfer functions for six environmental variables, including maximum depth, based on modern data from 35I European lakes. Water levels were reconstructed using the locally weighted-averaging technique (Juggins, 200I) which generates a "local" training set for each sample based on the 30 closest analogs in the data base. Diatom-inferred chemical variables (i.e. nutrients, silica, conductivity, $\mathrm{pH}$ ) were compared with diatom-inferred maximum depth, autecology of major diatom taxa, and pollen data to identify three main climate phases during the Eemian interglacial; an early climatic optimum ( $\sim 8000$ years), a cooler wetter period ( $\sim$ 7000 years) and a final warming ( $\sim$ 2000 years). Rioual et al. (2007) clearly demonstrate that detailed information on long-term climate can be obtained through the application of freshwater diatom-inferred depth reconstructions in conjunction with other environmental variables.

\subsection{Summary}

The ability to determine water-level changes in freshwater systems is an important tool for use in reconstructing past climate and predicting future climate change, and in geologic and environmental studies. Although complex interactions affect diatom signals in freshwater lakes, multiple responses can be utilized to quantitatively reconstruct water levels from freshwater diatom assemblages. Growth-habit changes based on depth distributions (i.e. benthic vs. planktonic) produce the most reliable evidence of water-level change. Autecological diatom response signals to changes in the physical-chemical 


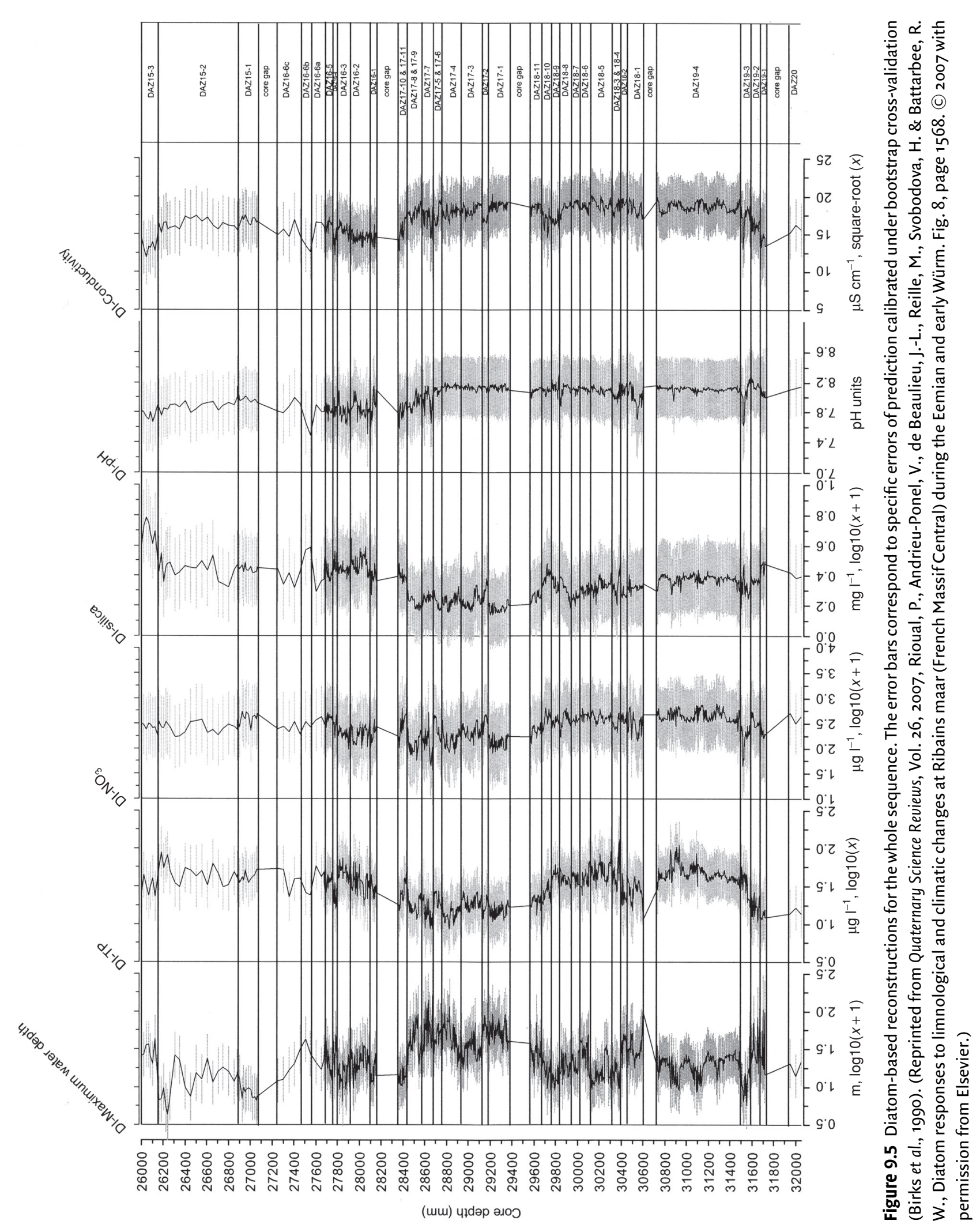


environment can also be used. The development of quantitative diatom-inferred depth models to reconstruct water level in freshwater systems has greatly improved our understanding of past climatic and environmental change. However, it must be emphasized that depth reconstructions from freshwater diatom data should be implemented with caution. Many of the authors cited have stressed the importance of understanding the system under investigation and use of independent corroborating evidence before valid reconstructions can be made. The diatom signals observed are open to alternative interpretations. This difficulty is partly responsible for the few quantitative reconstructions found in freshwater systems. Increased efforts with more nearshore and multiple-core analysis are needed to strengthen the interpretation of the diatom data, and more diatom-depth calibration studies are needed, as well as investigations of diatom nutrient, light, and temperature interactions in relation to depth. We still lack large regional data bases for many freshwater lake regions and these should include lake depth. Diatom-inferred water-level reconstructions from multiple lakes can then be combined into regional climate reconstructions (Digerfeldt, 1998) and regional data assembled into wider-ranging continental reconstructions (e.g. Harrison et al., 1996).

\section{Acknowledgements}

We would like to thank past collaborators: Jingrong Yang, John Anderson, Philip Barker, the late J. Platt Bradbury, Regine Jahn, André Lotter, Curt Stager for information, reprints, and discussions on their work for the first edition and, most importantly, to previous co-author Hamish Duthie for his invaluable insight, writing, and his significant contributions in developing quantitative methods for freshwater lake-level reconstruction. Thank you to our reviewers for their valuable comments.

\section{References}

Barker, P. A., Roberts, N., Lamb, H. F., Van Der Kaars, S., \& Benfaddour, A. (1994). Interpretation of Holocene lake-level change from diatom assemblages in Lake Sidi Ali, Middle Atlas, Morocco. Journal of Paleolimnology, I2, 223-4.

Battarbee, R. W. (2000). Palaeolimnological approaches to climate change, with special regard to the biological record. Quaternary Science Reviews, 19, 107-24.

Bergner, A. G. N. \& Trauth, M. H. (2004). Comparison of the hydrological and hydrochemical evolution of Lake Naivasha (Kenya) during three highstands between 175 and 60 kyr BP. Palaeogeography, Palaeoclimatology, Palaeoecology, 215, 17-36.
Birks, H. J. B., Line, J. M., Juggins, S., Stevenson, A. C., \& ter Braak, C.J. F. (1990). Diatoms and $\mathrm{pH}$ reconstruction. Philosophical Transactions of the Royal Society London, B 327, 263-78.

Björck, S., Noe-Nygaard, N., Wolin, J., et al. (2000). Eemian lake development, hydrology and climate-a multi-stratigraphic study of the Hollerup site in Denmark. Quaternary Science Reviews, I9, $509-36$.

Bradbury, J. P., Cumming, B., \& Laird, K. (2002). A I500-year record of climatic and environmental change in Minnesota III: measures of past primary productivity. Journal of Paleolimnology, 27, 32I40.

Brugam, R. B., McKeever, K., \& Kolesa, L. (1998). A diatom-inferred water depth reconstruction for an Upper Peninsula, Michigan, lake. Journal of Paleolimnology, 20, 267-76.

Bunting, M. J., Duthie, H. C., Campbell, D. R., Warner, B. G., \& Turner, L. J. (I997). A paleoecological record of recent environmental change at Big Creek Marsh, Long Point, Lake Erie. Journal of Great Lakes Research, 23, 349-68.

Coops, H., Beklioglu, M., \& Crisman, T. L. (2003). The role of waterlevel fluctuations in shallow lake ecosystems - workshop conclusions. Hydrobiologia, 506-509, 23-7.

Dearing, J. A. (1997). Sedimentary indicators of lake-level changes in the humid temperate zone: a critical review. Journal of Paleolimnology, I8, I-I4.

Delorme, L. D., Duthie, H. C., Esterby, S. R., Smith, S. M., \& Harper, N. S. (1986). Prehistoric inferred $\mathrm{pH}$ changes in Batchawana Lake, Ontario from sedimentary diatom assemblages. Archiv für Hydrobiologie, 108, I-22.

Digerfeldt, G. (1986). Studies on past lake level fluctuations. In Handbook of Holocene Palaeoecology and Palaeohydrology, ed. B. E. Berglund, New York: John Wiley \& Sons, pp. 127-43.

Digerfeldt, G. (1998). Reconstruction and of Holocene lakelevel changes in southern Sweden: technique and results. Paläoklimaforshung, 25, 87-98.

Duthie, H. C., Yang, J-R., Edwards, T. W. D., Wolfe, B. B., \& Warner, B. G. (1996). Hamilton Harbour, Ontario: 8300 years of environmental change inferred from microfossil and isotopic analyses. Journal of Paleolimnology, 15, 79-97.

Earle, J. C., Duthie, H. C., Glooschenko, W. A., \& Hamilton, P. B. (I988). Factors affecting the spatial distribution of diatoms on the surface sediments of three Precambrian Shield lakes. Canadian Journal of Fisheries and Aquatic Sciences, 45, 469-78.

Ekblom, A. \& Stabell, B. (2008). Paleohydrology of Lake Nhaucati (southern Mozambique), $\sim 400 \mathrm{AD}$ to present. Journal of Paleolimnology, 40, II27-4I.

Fahnenstiel, G. L. \& Scavia, D. (1987). Dynamics of Lake Michigan phytoplankton: the deep chlorophyll layer. Journal of Great Lakes Research, 13, 285-95.

Finkelstein, S. A. \& Davis, A. M. (2006). Paleoenvironmental records of water level and climatic changes from the middle to late Holocene at a Lake Erie coastal wetland, Ontario, Canada. Quaternary Research, 65, 33-43.

Finkelstein, S. A., Peros, M. C., \& Davis, A. M. (2005). Late Holocene paleoenvironmental change in a Great Lakes coastal wetland: 
integrating pollen and diatom datasets. Journal of Paleolimnology, 33, I-I2.

Gaillard, M.-J., Dearing, J. A., El-Dauoushy, F., Enell, M., \& Håkansson, H. (199I). A late Holocene record of land-use history, soil erosion, lake trophy and lake-level fluctuations at Bjäresjösjön (south Sweden). Journal of Paleolimnology, 6, 5I-8I.

Harrison, S. P., Yu, G., \& Tarasov, P. E. (1996). Late Quaternary lakelevel record from northern Eurasia. Quaternary Research, 45, ${ }_{3} 8-$ 59.

Heinsalu, A., Luup, H., Alliksaar, T., Nõges, P., \& Nõges, T. (2008). Water level changes in a large shallow lake as reflected by the plankton: periphyton-ratio of sedimentary diatoms. Hydrobiologia, 599, 23-30.

Jeppesen, E., Jensen, J. P., Sondergaard, M., Lauridsen, T., \& Land kildehus, F. (2000). Trophic structure, species richness and biodiversity in Danish lakes: changes along a phosphorus gradient Freshwater Biology, 45, 20I-2I8.

Juggins, S. (200I). The European Diatom Database. University of Newcastle, Newcastle. See http://craticula.ncl.ac.uk/Eddi/jsp/help. jsp.

Juggins, S. (2007). C2 Version I.5 User guide. Software for ecological and palaeoecological data analysis and visualization. Newcastle upon Tyne: Newcastle University.

Karrow P. F. \& Calkin P. E. (eds.), (1985). Quaternary Evolution of the Great Lakes. Geological Association of Canada Special Paper 30.

Kingston, J. C., Lowe, R. E., Stoermer, E. F., \& Ladewski, T. B. (1983) Spatial and temporal distribution of benthic diatoms in northern Lake Michigan. Ecology, 64, 1566-80.

Krabbenhoft, D. P. \& Webster, K. E. (I995). Transient hydrological controls on the chemistry of a seepage lake. Water Resources Research, 3I, 2295-305.

Laird, K. R. \& Cumming, B. F. (2008). Reconstruction of Holocene lake level from diatoms, chrysophytes and organic matter in a drainage lake from the Experimental Lakes Area (northwestern Ontario, Canada). Quaternary Research, 69, 292-305.

Laird, K. R. \& Cumming, B. F. (2009). Diatom-inferred lake level from near-shore cores in a drainage lake from the Experimental Lakes Area, northwestern Ontario, Canada. Journal of Paleolimnology, 42, $65-80$.

Larsen, C. E. \& Schaetzl R. (200I). Origin and evolution of the Great Lakes. Journal of Great Lakes Research, 27, 518-46.

Lewis, C. F. M, Karrow P. F., Blasco S. M., et al. (2008). Evolution of lakes in the Huron basin: deglaciation to present. Aquatic Ecosystem Health \& Management, II, $127-36$.

Lotter, A. (I988). Past water-level fluctuations at Lake Rotsee (Switzerland), evidenced by diatom analysis. In Proceedings of Nordic Diatomist Meeting, Stockholm, 1987, Department of Quaternary Research (USDQR) Report 12, Stockholm: University of Stockholm, pp. 4755 .

Lotter, A. F. \& Bigler, C. (2000). Do diatoms in the Swiss Alps reflect the length of ice-cover? Aquatic Sciences, 62, I25-4I.

Moos, M. T., Laird, K. R., \& Cumming, B. F. (2005). Diatom assemblages and water depth in Lake 239 (ELA, Ont.): implications for paleoclimatic studies. Journal of Paleolimnology, 34, 217-27.
Moos, M. T., Laird, K. R., \& Cumming, B. F. (2009). Climate-related eutrophication of a small boreal lake in northwestern Ontario: a palaeolimnological perspective. The Holocene, 19, 359-67.

Moser, K. A., Korhola, A., Weckström, J., et al. (2000). Paleohydrology inferred from diatoms in northern latitude regions. Journal of Paleolimnology, 24, 93-107.

Nõges, T., Nõges, P., \& Laugaste, R. (2003). Water level as the mediator between climate change and phytoplankton composition in a large shallow temperate lake. Hydrobiologia, 506-509, 25763.

Nguetsop, V. F., Servant-Vildart, S., \& Servant, M. (2004). Lat Holocene climatic changes in west Africa, a high resolution diatom record from equatorial Cameroon. Quaternary Science Review, 23, 59I-609.

Punning, J.-M. \& Puusepp, L. (2007). Diatom assemblages in sediments of Lake Juusa, southern Estonia with an assessment of their habitat. Hydrobiologia, 586, 27-4I.

Rautio, M., Sorvari, S., \& Korhola, A. (2000). Diatom and crustacean zooplankton communities, their seasonal variability and representation in the sediments of subarctic Lake Saanajärvi. Journal of Limnology, 59 (suppl. r), 8I-96.

Richardson, J. L. (1969). Former lake-level fluctuations - their recog nition and interpretation. Mitteilungen International Vereiningung für Theoretische und Angewandte Limnologie, 17, 78-93.

Rioual, P., Andrieu-Ponel, V., de Beaulieu, J.-L., et al. (2007). Diatom responses to limnological and climatic changes at Ribains maar (French Massif Central) during the Eemian and early Würm. Quaternary Science Reviews, 26, 1557-609.

Rippey, B., Anderson, N. J., \& Foy, R.H. (I997). Accuracy of diatominferred total phosphorus concentrations and the accelerated eutrophication of a lake due to reduced flushing and increased internal loading. Canadian Journal of Fisheries and Aquatic Sciences, $54,2637-46$.

Round, F. E. (Ig6I). Studies on bottom-living algae in some lakes of the English Lake District. Part VI. The effect of depth on the epipelic algal community. Journal of Ecology, 49, 245-54.

Sánchez-Castillo, P. M., Linares-Cuesta, J. E., \& Fernández-Moreno, D. (2008). Changes in epilithic diatom assemblages in a Mediterranean high mountain lake (Laguna de La Caldera, Sierra Nevada, Spain) after a period of drought. Journal of Limnology, 67, 4955.

Schmidt, R., Kamenik, C., Lange-Bertalot, H. \& Klee, R. (2004). Fragilaria and Staurosira (Bacillariophyceae) from sediment surfaces of 40 lakes in the Austrian Alps in relation to environmental variables, and their potential for palaeoclimatology. Journal of Limnology, 63, 171-89.

Shkarpa, V. (2006). Climate and human settlement effects on Silver Lake Ohio. Unpublished M.Sc. thesis, Cleveland State University, Cleveland, $\mathrm{OH}$.

Smol, J. P. (I988). Paleoclimate proxy data from freshwater arctic diatoms. Verhandlungen der Internationalen Vereinigung fur Theoretische und Angewandte Limnologie, 23, 837-44.

Smol, J. P. (2008). Pollution of Lakes and Rivers: A Paleoenvironmental Perspective, 2nd edition, Hoboken: John Wiley \& Sons. 
Smol, J. P. \& Cumming, B. F. (2000). Tracking long-term changes in climate using algal indicators in lake sediments. Journal of Phycology, 36, 986-roir.

Stager, J. C., Cumming, B., \& Meeker, L. (1997). A high-resolution II,400-year diatom record from lake Victoria, East Africa. Quaternary Research 47, 8I-9.

Stager, J. C., Ryves, D., Cumming, B. F., Meeker, L. D., \& Beer, J. (2005). Solarvariability and the levels of Lake Victoria, East Africa, during the last millennium. Journal of Paleolimnology, 33, 243-5I.

Stevenson, R. J. \& Stoermer, E. F. (I98I). Quantitative differences in benthic algal communities along a depth gradient in Lake Michigan. Journal of Phycology, 17, 29-36.

Stone, J. R. \& Fritz, S. C. (2004). Three-dimensional modeling of lacustrine diatom habitat areas: improving paleolimnological interpretation of planktic : benthic ratios. Limnology \& Oceanography, 49, I540-8.

Street-Perrott, F. A. \& Harrison, S. P. (1985). Lake levels and climate reconstruction. In Paleoclimate Analysis and Modelling, ed. A.D. Hecht, New York, NY: John Wiley and Sons, pp. 29I-340.

Tapia, P. M., Fritz, S. C., Baker, P. A., Seltzer, G. O., \& Dunbar, R. B. (2003). A late quaternary diatom record of tropical climatic history from Lake Titicaca (Peru and Bolivia). Palaeogeography, Palaeoclimatology, Palaeoecology, 194, I39-64.

Tarasov, P. E., Harrison, S. P., Saarse, L., et al. (1994). Lake Status Records from the Former Soviet Union Mongolia: Data Base Documentation. Paleoclimatology Publications Series Report no. 2. Boulder, CO: World Data Center-A for Paleoclimatology, NOAA Paleoclimatology Program.

Tarasov, P., Dorofeyuk, N., \& Metel'tseva, E. (2000). Holocene vegetation and climate changes in Hoton-Nur basin, northwest Mongolia. BOREAS, 29, II7-26.

Turner, M. A., Heubert, D. B., Findlay, D. L., et al. (2005). Divergent impacts of experimental lake-level drawdown on planktonic and benthic plant communities in a boreal forest lake. Canadian Journal of Fisheries and Aquatic Sciences, 62, 99I-I003.

Vadeboncoeur, Y., Peterson, G., Vander Zanden, M. J., \& Kalff, J. (2008). Benthic algal production across lake size gradients: interactions among morphometry, nutrients and light. Ecology, $89,2542-52$.

Verschuren, D., Laird, K. R., \& Cumming, B. F. (2000). Rainfall and drought in equatorial east Africa during the past I, I00 years. Nature, 403, 410-I4.

Voigt, R., Grüger, E., Baier, J. \& Meischner, D. (2008). Seasonal variability of Holocene climate: a palaeolimnological study on varved sediments in Lake Jues (Harz Mountains, Germany). Journal of Paleolimnology, 40, I02I-52.

Wetzel, R. G. (200I). Limnology Lake and River Ecosystems, 3rd edition, San Diego, CA: Academic Press.

Wolfe B. B., Edwards T. W. D., \& Duthie, H. C. (2000). A 6000year record of interaction between Hamilton Harbour and Lake Ontario: quantitative assessment of recent hydrologic disturbance using ${ }^{13} \mathrm{C}$ in lake sediment cellulose. Aquatic Ecosystem Health Management, 3, 47-54.

Wolin, J. A. (1996). Late Holocene lake-level fluctuations in Lower Herring Lake, Michigan, U.S.A. Journal of Paleolimnology, 15, I945 .

Wolin, J. A. \& Duthie, H. C. (1999). Diatoms as indicators of water level change in freshwater lakes, In The Diatoms: Applications for Environmental and Earth Sciences, ed. E. F. Stoermer \& J. P. Smol, Cambridge: Cambridge University Press, pp. $183-202$.

Wolin, J. A. \& Stoermer, E. F. (2005). Response of a Lake Michigan coastal lake to anthropogenic catchment disturbance. Journal of Paleolimnology, 33, 73-94.

Xue, B., Qu, W., Wang, S., Ma, Y., \& Dickman, M. D. (2003). Lake level changes documented by sediment properties and diatom of Hulum Lake, China since the late Glacial. Hydrobiologia, 498, I33-4I.

Yang, J-R. \& Duthie, H. C. (I995). Regression and weighted averaging models relating surficial diatom assemblages to water depth in Lake Ontario. Journal of Great Lakes Research, 2I, 84-94.

Yu, G. \& Harrison, S.P. (I995). Lake Status Records from Europe: Data Base Documentation. Paleoclimatology Publications Series Report no. 3. Boulder, Colorado:World Data Center-A for Paleoclimatology, NOAA Paleoclimatology Program. 